\title{
Enhancement of Rabbit Protein S Anticoagulant Cofactor Activity In Vivo by Modulation of the Protein S
}

\section{C4B Binding Protein Interaction}

Ralph E. Weinstein and Frederick J. Walker

Departments of Medicine and Laboratory Medicine, University of Connecticut School of Medicine, and the American Red Cross, Farmington, Connecticut 06032

\begin{abstract}
The carboxy-terminal region of protein $S$ has been recently been observed to be involved in the interaction between protein S and C4b-binding protein (Walker, F. J. 1989. J. Biol. Chem. 264:17645-17658). A synthetic peptide, GVQLDLDEAI, corresponding to that region of protein $S$ has been used to investigate the protein $\mathbf{S} / \mathbf{C} 4 \mathrm{~b}$-binding protein interaction in vitro and in vivo. Rabbit activated protein $\mathrm{C}$ possesses speciesspecific anticoagulant activity for which rabbit protein $\mathrm{S}$ functions as a cofactor. In plasma, rabbit protein $S$ is found in complex with C4b-binding protein. GVQLDLDEAI can inhibit this interaction, resulting in enhancement of the anticoagulant activity of rabbit activated protein $C$. The effect of the peptide can be blocked by the concurrent addition of human or rabbit $\mathrm{C} 4 \mathrm{~b}-\mathrm{binding}$ protein. When infused into rabbits, GVQLDLDEAI was cleared from the circulation with a halflife of $80 \mathrm{~min}$. This is significantly less rapid than the clearance of similarly sized control peptides (half-life of $15 \mathrm{~min}$ ), but much more than that of bovine protein $\mathrm{S}$, a much larger protein (half-life of $15 \mathrm{~h}$ ). Plasma samples removed from the rabbits after infusion with GVQLDLDEAI were found to have increased concentrations of free protein $S$ and to show enhanced anticoagulation by rabbit activated protein $\mathrm{C}$ ex vivo in a dosedependent manner. The concentration for half-maximal effect $(5 \mu \mathrm{M})$ was very similar to that observed in vitro. These results suggest that the formation of a complex between protein $S$ and $\mathrm{C} 4 \mathrm{~b}$-binding protein is important in the regulation of protein $\mathrm{S}$ activity in vivo, and that modulation of this interaction allows one to influence the anticoagulant activity of the protein $\mathrm{C}$ pathway. (J. Clin. Invest. 1990. 86:1928-1935.) Key words: protein $\mathrm{C} \bullet$ peptide $\bullet$ thrombosis $\bullet$ species specificity $\bullet$ purification
\end{abstract}

\section{Introduction}

Protein $\mathrm{C}$ is a vitamin $\mathrm{K}$-dependent protein found in the blood plasma. It can be converted to its active form, activated

This work was presented in part at the Annual Meeting of the AAP/ ASCI/AFCR, Washington, DC, April 1989 (Weinstein, R. E., and F. J. Walker. 1989. Clin. Res. 37:391a. [Abstr.]), and at the 31st Annual Meeting of the American Society of Hematology (Weinstein, R. E., and F. J. Walker. 1989. Blood. 74:174a. [Abstr.]).

Address reprint requests to Frederick J. Walker, Ph.D., American Red Cross, 209 Farmington Ave., Farmington, CT 06032.

Received for publication 9 April 1990 and in revised form 6 July 1990.

J. Clin. Invest.

(c) The American Society for Clinical Investigation, Inc.

0021-9738/90/12/1928/08 $\$ 2.00$

Volume 86, December 1990, 1928-1935 protein $\mathrm{C}$ by thrombin, when in complex with the endothelial cell surface protein thrombomodulin (1). Activated protein $\mathrm{C}$ is a serine protease that has both anticoagulant (2-4) and profibrinolytic activities $(4,5)$. Its anticoagulant activity is through the proteolytic inactivation of activated factor $\mathrm{V}(2,6$, 7) and factor VIII (7-9). Proteolysis of factors V and VIII takes place on membranes, and maximum activity of activated protein $C$ requires the presence of a cofactor, protein $S$ (10). Protein $\mathrm{S}$, also a vitamin $\mathrm{K}$-dependent protein, has been isolated from human, bovine, and rabbit plasma (11-14). Protein S has been shown to enhance the rate of inactivation of both factors V $(10,15)$ and VIII $(9,16)$ by activated protein C. Species specificity of the anticoagulant activity of activated protein $\mathrm{C}$ was first documented in 1972 (17) and was later shown to be due to its interaction with protein $S$ (18).

Protein $\mathrm{S}$ is unique in the family of vitamin $\mathrm{K}$-dependent proteins because it is a cofactor rather than a zymogen of a serine protease. The amino acid sequences of bovine (19) and human (20) protein $S$ have carboxy-terminal regions homologous to rat androgen-binding protein rather than the trypsinlike domains found in the other vitamin $\mathrm{K}$-dependent proteins (21). Protein S activity in humans appears to be regulated by a unique mechanism. It does not require activation for expression of its anticoagulant cofactor activity as the single chain form found in plasma is active. In human blood, 40\% of the protein $\mathrm{S}$ is found in complex with $\mathrm{C} 4 \mathrm{~b}$-binding protein (22). When in complex with this protein, protein $S$ is unable to act as a cofactor for activated protein $C$ (23). On the other hand, bovine protein $\mathrm{S}$ circulates primarily as free protein $\mathrm{S}$ because bovine $\mathrm{C} 4 \mathrm{~b}$-binding protein does not interact strongly with protein $S$ (23). Bovine blood contains another protein $S$ binding protein which appears to enhance the anticoagulant activity of bovine protein $S(24)$. The regulation of protein $S$ in other species is unknown.

Recently, a synthetic peptide corresponding to a portion of protein $S$ that is homologous to androgen binding protein has been found to interfere with the interaction between human protein $\mathrm{S}$ and $\mathrm{C} 4 \mathrm{~b}$-binding protein, resulting in enhancement of the anticoagulant activity of activated protein $\mathrm{C}(25)$. To test the significance of this observation in vivo, we developed a rabbit model in which purified rabbit protein $C$ and protein $S$ have been employed to ensure that species specificity did not affect the results. In this paper, the role of protein $S$ in the regulation of the rabbit protein $C$ anticoagulant pathway is described and the effect on coagulation of perturbation of the protein S/C4b-binding protein interaction by a synthetic peptide in vivo is investigated.

\section{Methods}

Preparation of proteins. Rabbit protein $\mathrm{C}$ was purified either by a method previously described (14) or by immunoaffinity chromatogra- 
phy using the monoclonal antibody PC121 coupled to agarose. Human protein $C(26)$ and bovine protein $C(6)$ were prepared using previously described methods. Protein $C$ was activated using the specific protein $\mathrm{C}$ activator isolated from the venom of Agkistrodon contortrix contortrix as described previously (27). Bovine (10) and rabbit (14) protein $S$ were purified using previously described methods. Bovine factor $\mathrm{X}$ was prepared according to the method described by Stenflo (28) and activated as described previously (29). Human C4bbinding protein was purified according to the method of Dahlback (30). Protein $\mathrm{S}$ which was bound to the $\mathrm{C} 4 \mathrm{~b}$-binding protein was removed by gel filtration in $3 \mathrm{M} \mathrm{NaSCN}$ buffered with $0.02 \mathrm{M}$ Tris- $\mathrm{HCl}$ $\mathrm{pH}$ 7.5. Thiocyanate was removed from the $\mathrm{C} 4 \mathrm{~b}$-binding protein by gel filtration.

Protein $\mathrm{S}$ was radiolabeled by the chloramine $\mathrm{T}$ method (31). Radiolabeled protein $S$ had a specific activity of $2,000 \mathrm{cpm} / \mathrm{ng}$ and retained anticoagulant cofactor activity. When radiolabeled rabbit protein $\mathrm{S}$ was electrophoresed in a $10 \%$ SDS-PAGE followed by autoradiography, a closely spaced doublet at $62,000 \mathrm{kD}$ was seen that was similar to the pattern of unlabeled rabbit protein $S$ (14).

Synthetic peptides. The peptides GVQLDLDEAI (corresponding to amino acids $605-614$ of human protein S), DGEQLADLIV (scrambled amino acids 605-614), and PINPRLDG (amino acids 400-407) were synthesized by Peninsula Laboratories, Inc. (Belmont, CA). The peptides were $>90 \%$ homogenous as determined by HPLC and contained the correct ratio of amino acids as determined by amino acid analysis.

The synthetic peptides were labeled with 5-(4,6-dichlorotriazinyl) aminofluorescein (5-DTAF) according to the method of Morrison (32). Unreacted 5-DTAF was removed from fluorescein-labeled peptide by gel filtration over a column of Sephadex G-10.

Antibodies. A monoclonal antibody, PC 121, which recognizes an epitope on human protein $C$ that includes the activation peptide sequence, was kindly provided by Dr. D. Strickland (American Red Cross, Jerome Holland Laboratory, Rockville, MD). PC 121 recognized purified rabbit protein C on ELISA and on immunoblots. Polyclonal antibodies to rabbit protein $\mathrm{C}$ and protein $\mathrm{S}$ were raised in guinea pigs according to the method of Vaitukaitis (33).

Anticoagulant assay. The anticoagulant activity of activated protein $\mathrm{C}$ was measured by a method reported earlier (34) in which the effect of activated protein $\mathrm{C}$ on factor Xa-initiated clotting of rabbit plasma was determined by comparing the clotting time in the presence or absence of activated protein C. Briefly, $100 \mu \mathrm{l}$ of bovine brain phospholipids $(0.5 \mathrm{mg} / \mathrm{ml})$ diluted in $0.02 \mathrm{M}$ Tris $\mathrm{HCl}, 0.10 \mathrm{M} \mathrm{NaCl}, 1$ $\mathrm{mg} / \mathrm{ml} \mathrm{BSA}, \mathrm{pH} 7.5$ (TBSA), $100 \mu \mathrm{l}$ of bovine factor Xa diluted in TBSA, and $100 \mu$ lof rabbit plasma were incubated at $37^{\circ} \mathrm{C}$ for $2 \mathrm{~min} .5$ $\mu \mathrm{l}$ of activated protein $\mathrm{C}$ was added and clotting initiated by adding 100 $\mu l$ of $0.025 \mathrm{M} \mathrm{CaCl}_{2}$. A standard curve was prepared using serial dilutions of bovine factor $\mathrm{Xa}$ and the anticoagulant effect defined as "percent inhibition of factor Xa activity." The ability of rabbit protein $\mathrm{S}$ to serve as a cofactor for the anticoagulant activity of rabbit protein $\mathrm{C}$ was tested using a modification of the above assay, as described earlier (34). Briefly, bovine plasma was used in place of rabbit plasma and 10 $\mu \mathrm{l}$ of samples to be tested for protein $\mathrm{S}$ activity were also added.

Determination of free protein $S$. The concentration of free protein $\mathrm{S}$ was measured in one of three ways. In the first method ("PEG precipitation") ${ }^{125}$ I-labeled protein $\mathrm{S}$ (10 $\mathrm{ng} / \mathrm{ml}$ final concentration) was added to plasma in the presence or absence of synthetic peptides and incubated at $37^{\circ} \mathrm{C}$ for $2 \mathrm{~h}$. A $25 \%$ solution of polyethylene glycol 8000 (PEG 8000) was added to a final concentration of $6 \%$, the samples mixed and incubated on ice for $30 \mathrm{~min}$, and the precipitate removed by centrifugation in a microfuge (Beckman Instruments, Inc., Fullerton, CA) at full speed for $5 \mathrm{~min}$. A sample was removed from the supernatant and counted in a gamma counter. Although 3-4\% PEG is used to measure the concentration of free protein $\mathrm{S}$ in human plasma, precipitation with 6\% PEG was chosen on the basis of the following observation. Various concentrations of PEG were added to rabbit plasma, the mixtures were centrifuged, and the supernatants were electrophoresed on agarose gels. Autoradiography of the gels revealed that the 6\% PEG supernatant contained free protein $\mathrm{S}$ but not the high-molecular weight protein S/C4b-binding protein complex (data not shown).

Alternatively, $25 \mu \mathrm{l}$ of ${ }^{125} \mathrm{I}$ rabbit protein $\mathrm{S}$ was added to $475 \mu \mathrm{l}$ of rabbit plasma, and, after incubation at $37^{\circ} \mathrm{C}$ for $2 \mathrm{~h}$, the sample gel filtered over a $0.9 \times 55 \mathrm{~cm}$ column of Ultragel ACA 34 as described by Dahlback (22). As a control, ${ }^{125} \mathrm{I}$-labeled rabbit protein S plus $475 \mu \mathrm{l}$ of $0.02 \mathrm{M}$ Tris- $\mathrm{HCl}, 0.10 \mathrm{M} \mathrm{NaCl}$ buffer were gel filtered. The third method used was two-dimensional immunoelectrophoresis as described by Comp et al. (35). Samples of plasma in the presence or absence of synthetic peptides were first electrophoresed in $1 \%$ agarose in $0.08 \mathrm{M}$ Tris base, $0.024 \mathrm{M}$ tricine, $\mathrm{pH} 8.6$, with $0.3 \mathrm{mM}$ EDTA-Na $\mathrm{Na}_{4}$ (tricine buffer). The second-dimension gel contained 1\% guinea pig anti-rabbit protein $\mathrm{S}$ in tricine buffer.

Electrophoresis. Purity of proteins was assured by electrophoresis in SDS-PAGE according to Laemmli (36). Flat bed agarose electrophoresis was carried out by modifications of the method of Jeppson, as described by Dahlback (22). Gels were stained either with Coomassie brilliant blue or with silver nitrate (37).

Western immunoblotting. After SDS-PAGE, samples were electroblotted onto nitrocellulose for $1 \mathrm{~h}$ on a Jannsen semidry blotter. After blocking with 5\% Carnation Instant Milk, the blot was incubated overnight with guinea pig antibodies to rabbit protein $C$ or protein $S$. Peroxidase-conjugated goat anti-guinea pig IgG antibodies were added for an additional $4 \mathrm{~h}$ and the blot developed with 4 chloro-1-naphthol. The blots were washed three times with $0.02 \mathrm{M}$ Tris- $\mathrm{HCl}, 0.10 \mathrm{M}$ $\mathrm{NaCl}, \mathrm{pH} 7.5$, before and after incubation with the second antibody.

Autoradiography. Samples containing ${ }^{125} \mathrm{I}$ rabbit protein $\mathrm{S}$ were subjected to electrophoresis on agarose or SDS-PAGE, the gels dried and incubated at $-70^{\circ} \mathrm{C}$ with Kodak X-omat $\mathrm{AR}$ film, and the film developed using standard methods.

Animal studies. Male New Zealand White rabbits weighing between 3 and $5 \mathrm{~kg}$ were received from a single supplier and housed at the Center for Laboratory Animal Care at the University of Connecticut Health Center. Clearance of bovine protein $\mathrm{S}$ was measured after intravenous infusion of ${ }^{125} \mathrm{I}$ bovine protein $\mathrm{S}$ via the marginal ear vein of a rabbit lightly sedated with ketamine $\mathrm{HCl}$. Serial blood samples were collected in plastic syringes containing $3.8 \%$ sodium citrate ( $1: 9 \mathrm{vol} /$ vol) from an indwelling catheter in the contralateral ear artery, immediately centrifuged to obtain plasma, and radioactivity measured in a gamma counter. Clearance of the synthetic peptides GVQLDLDEAI and PINPRLDG was determined after intravenous injection of fluorescein-labeled peptide. Blood samples were obtained as described above and plasma immediately prepared by centrifugation. Plasma samples were analyzed by spectrofluorometry using a model 8000 spectrofluorometer (SLM Instruments Inc., Urbana, IL). Emission at $515 \mathrm{~nm}$ was measured (with appropriate blanks) after excitation at 492 $\mathrm{nm}$. The anticoagulant activity of exogenously added rabbit activated protein $\mathrm{C}$ and the concentration of free protein $\mathrm{S}$ were determined as described previously in plasma samples obtained from rabbits after administration of the synthetic peptides.

Statistical analysis. Slopes of lines were calculated using power regression analysis according to standard methods. Comparison of matched samples was accomplished by using Student's $t$ test.

\section{Results}

Characterization of rabbit protein $C$ anticoagulant activity Rabbit protein $\mathrm{C}$, like the human and bovine proteins, is a two-chain protein (14). After conversion to its active form, activated protein $C$, it is able to cleave small synthetic chromogenic substrates (14) and possesses potent anticoagulant activity in rabbit plasma (Fig. 1, bar 1 ). The anticoagulant activity of rabbit activated protein $C$ is species specific because rabbit activated protein $\mathrm{C}$ has little activity in bovine plasma (Fig. 1, bar 2).

Rabbit protein $S$ is a single-chain protein (14) and possesses no inherent protease activity (data not shown). How- 


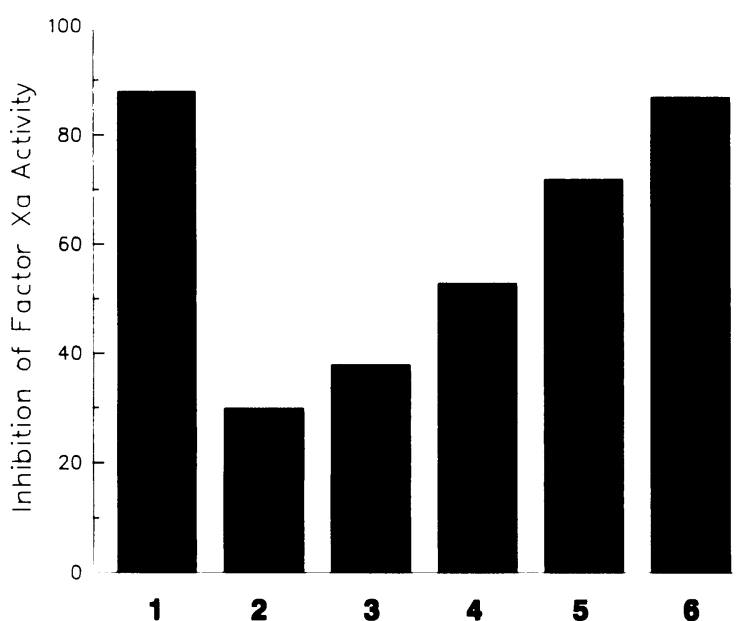

Figure 1. Anticoagulant activity in vitro of $67 \mathrm{nM}$ rabbit activated protein $C$ in rabbit (bar 1 ) and bovine plasma (bar 2). Effect of addition of increasing concentrations of rabbit protein S (bar 3. $20 \mathrm{nM}$; bar 4, $40 \mathrm{nM}$; bar 5, $300 \mathrm{nM}$; bar 6, $600 \mathrm{nM}$ ) on the anticoagulant activity of rabbit activated protein $C$ in bovine plasma. The data shown is representative of three experiments.

ever, because addition of rabbit protein $\mathrm{S}$ to bovine plasma imparts anticoagulant activity to rabbit activated protein $\mathrm{C}$ (Fig. 1, bars 3-6), it appears that rabbit protein $\mathrm{S}$ is a cofactor for expression of the anticoagulant activity of rabbit activated protein $\mathrm{C}$. Because human and bovine activated protein $\mathrm{C}$ have little anticoagulant activity in rabbit plasma (Fig. 2), it appears that rabbit protein $\mathrm{S}$ cannot act as a cofactor for the expression of anticoagulant activity by activated protein $\mathrm{C}$ of heterologous species. Thus, the anticoagulant activity of both rabbit activated protein $C$ and protein $S$ are species specific.

Although the formation of a protein S/C $4 b$-binding protein complex is felt to be important in the regulation of the anticoagulant cofactor activity of human protein $S$, the ratio of free to bound protein $\mathrm{S}$ in other animals is variable. For example, there is very little bound protein $S$ in bovine plasma (23).

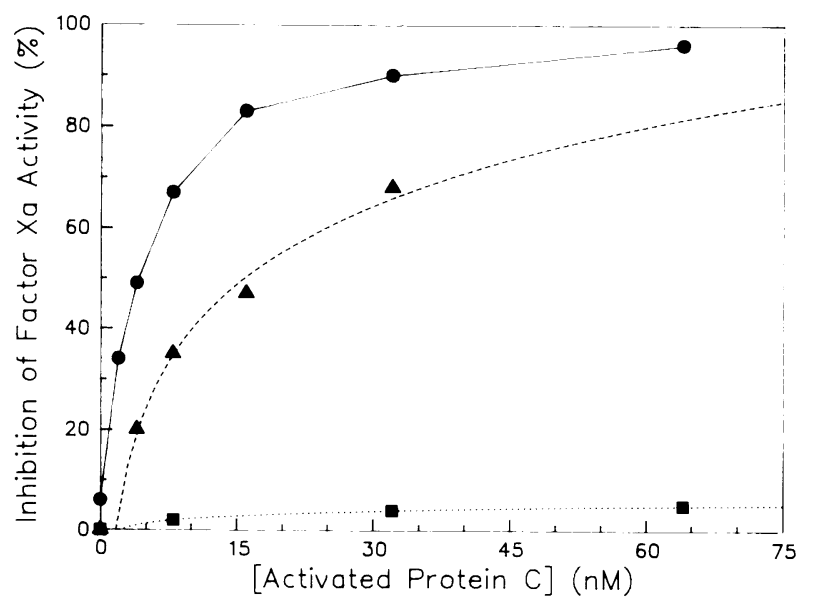

Figure 2. Anticoagulant activity in vitro of activated protein $\mathrm{C}$ in rabbit plasma. Rabbit (solid circles), human (solid triangles), and bovine (solid squares) activated protein $C$ were added to rabbit plasma and inhibition of factor $\mathrm{Xa}$ activity measured. The data shown is representative of three experiments.
To investigate the importance of this interaction in rabbit plasma, ${ }^{125}$ I-labeled rabbit protein $\mathrm{S}$ was added to rabbit plasma and the mixture then gel filtered over a column of Ultragel ACA 34. The radioactivity of the column fractions was measured and two major peaks were observed (Fig. $3 \mathrm{~A}$ ), a pattern very similar to that reported in human plasma (23). When samples taken from the individual column fractions were subjected to $6 \%$ native gel electrophoresis and subsequent autoradiography, the first peak was found to correspond to a very high-molecular weight band consistent with a protein $\mathrm{S} / \mathrm{C} 4 \mathrm{~b}$-binding protein complex and the second peak to a smaller protein consistent with free protein S (Fig. 3 B). A third peak that followed just behind that of free protein $S$ appears to be comprised of a small $(\sim 25-\mathrm{kD})$ protein. This is believed to result from proteolytic degradation of protein $\mathrm{S}$ during iodination and was variably present. ${ }^{125}$ I-labeled rabbit protein $\mathrm{S}$ alone eluted in a single peak corresponding to free protein $\mathrm{S}$ (Fig. $3 \mathrm{~A}$, dotted line). Thus, the high-molecular weight complex results from an interaction between rabbit protein $\mathrm{S}$ and a plasma protein rather than aggregates of rabbit protein $\mathrm{S}$. This data suggests that rabbit protein $\mathrm{S}$ forms a complex with rabbit $\mathrm{C} 4 \mathrm{~b}$-binding protein.

Modulation of protein $S$ activity in vitro. The peptide GVQLDLDEAI, which corresponds to amino acids 605-614 of the human protein $\mathrm{S}$ sequence, has been found to interfere with the protein $\mathrm{S} / \mathrm{C} 4 \mathrm{~b}$-binding protein interaction in human plasma (25). Because rabbit protein $\mathrm{S}$ has been found to have anticoagulant cofactor activity and appears to form a complex with rabbit $\mathrm{C} 4 \mathrm{~b}$-binding protein, it was postulated that if GVQLDLDEAI were to affect the protein S/C4b-binding protein interaction it would alter the anticoagulant cofactor activity of rabbit protein S. GVQLDLDEAI was found to enhance the anticoagulant activity of exogenously added rabbit activated protein $C$ (Fig. 4). The effect was dose-dependent with a half-maximal effect of $\sim 5 \mu \mathrm{M}$. Neither DGEQLADLIV (scrambled amino acids 605-614) nor PINPRLDG, which corresponds to amino acids 400-407 of the human protein $\mathrm{S}$ sequence, had any effect. Addition of GVQLDLDEAI had no effect on factor Xa activity in the absence of activated protein C (Fig. 4), indicating that its action was mediated by an effect on protein $\mathrm{C}$ anticoagulant activity rather than via a direct effect on coagulation. In the absence of added C4b-binding protein, $8 \mu \mathrm{M}$ and $42 \mu \mathrm{M}$ GVQLDLDEAI increased the anticoagulant activity of rabbit activated protein $\mathrm{C}$ in rabbit plasma from 37.6 to $50.37 \%(P<0.02)$ and $61.67 \%(P<0.02)$ respectively. Addition of exogenous $C 4 \mathrm{~b}$-binding protein (human or rabbit) blocked this effect (Fig. 5). This data supports a mechanism of action involving protein $S$ rather than a direct effect of GVQLDLDEAI on activated protein $C$.

The effect of GVQLDLDEAI on the distribution of rabbit protein $\mathrm{S}$ was then studied to further define its effect in rabbit plasma. When the distribution of free and bound ${ }^{125}$ I protein $S$ was determined by PEG precipitation, addition of GVQLDLDEAI was noted to cause an increase in the relative concentration of free protein $S$ in a dose-dependent fashion (Fig. 6). The half-maximal effect of the peptide $(5-10 \mu \mathrm{M})$ was very similar to that noted for its effect on coagulation. In addition, addition of GVQLDLDEAI to rabbit plasma decreased the concentration of protein $\mathrm{S}$ bound to $\mathrm{C} 4 \mathrm{~b}$-binding protein from $45.7 \pm 2.0 \%$ to $36.3 \pm 1.98 \%$ of total protein $S(P<0.02)$ when the distribution of protein $\mathrm{S}$ was measured by gel filtration (Fig. 7, $A$ and $B$ ). On two-dimensional immunoelectro- 


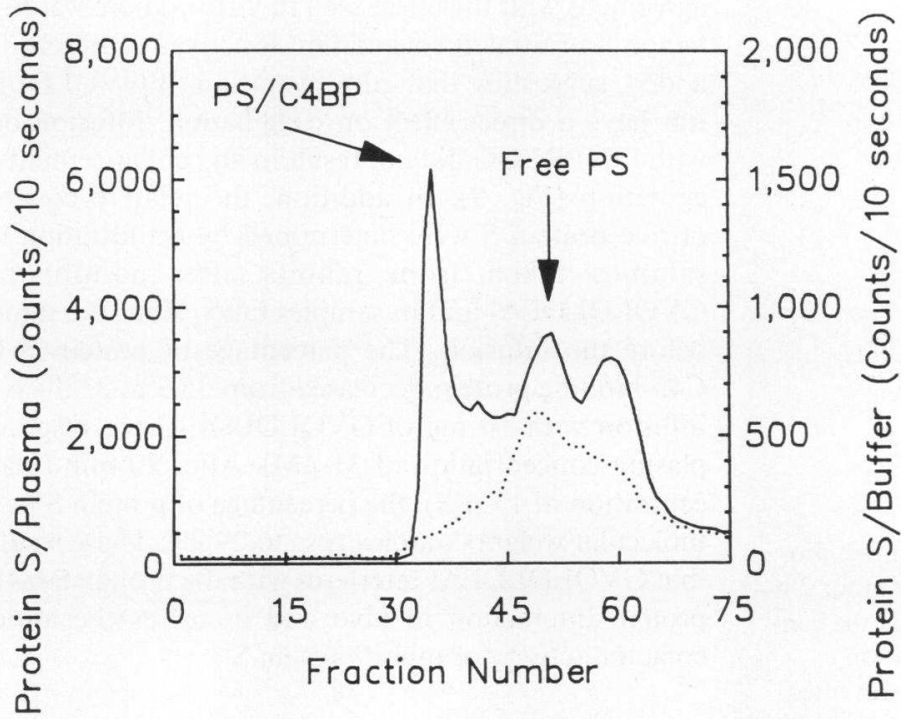

$\begin{array}{lllllllll}34 & 35 & 37 & 41 & 44 & 48 & 51 & 55 & 59\end{array}$

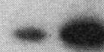

Figure 3. Interaction between protein $\mathrm{S}$ and $\mathrm{C} 4 \mathrm{~b}-$ binding protein in rabbit plasma. $(A)$ Gel filtration of mixture of $25 \mu \mathrm{l}^{125} \mathrm{I}$-labeled rabbit protein $\mathrm{S}$ and 475 $\mu \mathrm{l}$ rabbit plasma (solid line) or $25 \mu \mathrm{l}^{125} \mathrm{I}$-labeled plus $475 \mu 1$ TBSA (dotted line) over $0.9 \times 55 \mathrm{~cm}$ column of Ultragel ACA 34. 0.5-ml fractions were collected. (B) Autoradiography of column fractions from chromatography of ${ }^{125}$ I-labeled rabbit protein $S$ in rabbit plasma after electrophoresis on 6\% native PAGE.

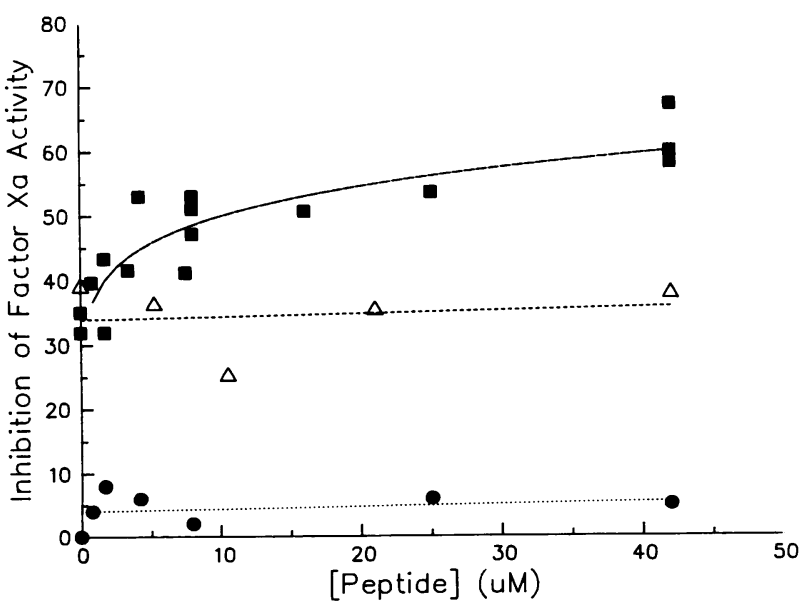

Figure 4. Enhancement of protein $\mathrm{C}$ anticoagulant activity in vitro by GVQLDLDEAI. Inhibition of factor $\mathrm{Xa}$ activity by $1 \mathrm{nM}$ rabbit activated protein C plus GVQLDLDEAI (solid squares), $1 \mathrm{nM}$ rabbit activated protein C plus DGEQLADLIV (open triangles), or GVQLDLDEAI alone (solid circles). The solid line (results of three experiments in which GVQLDLDEAI plus $1 \mathrm{nM}$ rabbit activated protein $C$ were added) was fitted by power regression analysis $\left(R^{2}\right.$ $=0.70)$.

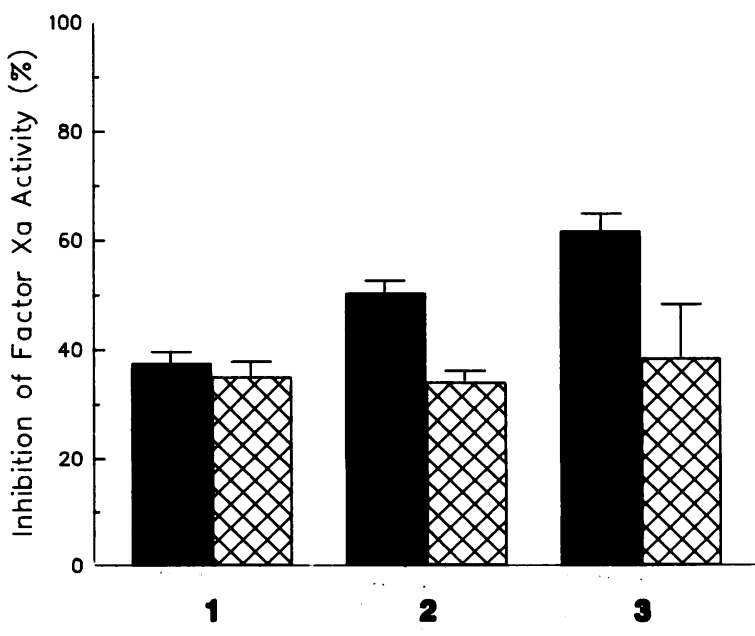

Figure 5. Antagonism of GVQLDLDEAI anticoagulant activity in vitro by human C4b-binding protein. Anticoagulant activity of $2 \mathbf{n M}$ rabbit activated protein $C$ (cluster 1 ), $2 \mathrm{nM}$ rabbit activated protein C plus $8 \mu \mathrm{M}$ GVQLDLDEAI (cluster 2), or $2 \mathrm{nM}$ rabbit activated protein C plus $40 \mu \mathrm{M}$ GVQLDLDEAI (cluster 3). Results are the mean $\pm S D$ of three experiments. 


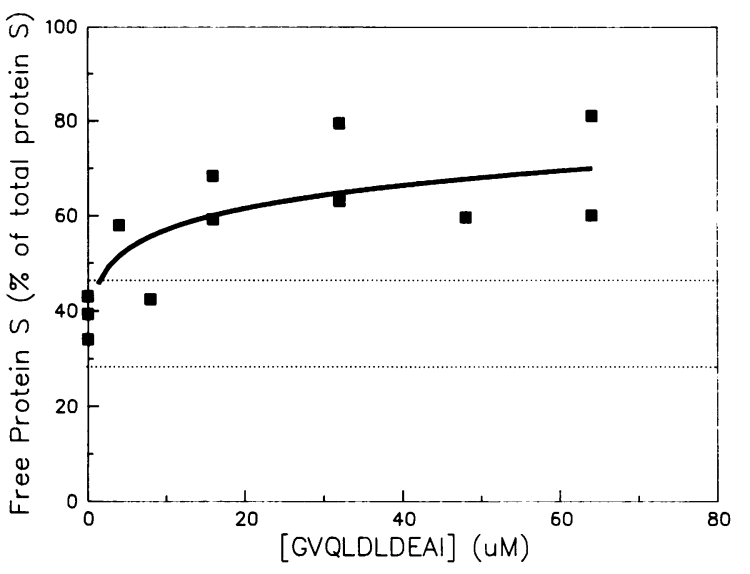

Figure 6. Effect of GVQLDLDEAI on the concentration of free protein $\mathrm{S}$ in vitro in rabbit plasma. Rabbit plasma was incubated for $2 \mathrm{~h}$ at $37^{\circ} \mathrm{C}$ with varying concentrations of GVQLDLDEAI and the concentration of free protein S measured by the PEG precipitation method. Results of three experiments are shown. The line was fitted by power regression analysis $\left(R^{2}=0.30\right) .95 \%$ confidence interval for the concentration of free protein $S$ without added GVQLDLDEAI was $29-47 \%$ (dotted lines).

phoresis the relative proportion of free protein S (indicated by the arrows) was increased in plasma samples containing GVQLDLDEAI (Fig. 7, $C$ and $D$ ). The magnitude of the effect observed using these techniques was less than that measured by PEG precipitation. Because the interaction between GVQLDLDEAI and C4b-binding protein appears to be an order of magnitude weaker than that of protein $S$ and $C 4 b-$ binding protein (30), it is possible that displacement of the peptide from C4b-binding protein may occur during electrophoresis or gel filtration, resulting in a diminished effect.

Modulation of protein $S$ activity in vivo. The in vitro experiments indicated that rabbit protein $S$ is regulated by its interaction with $\mathrm{C} 4 \mathrm{~b}$-binding protein and that displacement of protein $\mathrm{S}$ from $\mathrm{C} 4 \mathrm{~b}$-binding protein results in enhancement of its anticoagulant cofactor activity in vitro. To test the importance of this phenomenon in vivo, we infused rabbits with either GVQLDLDEAI, DGEQLADLIV, or PINPRLDG. Compared with a large protein like bovine protein $S$ (half-life of $15 \mathrm{~h}$ after injection), GVQLDLDEAI was cleared very rapidly from the rabbit circulation (half-life of $80 \mathrm{~min}$; Fig. 8). However, the clearance of GVQLDLDEAI was much less rapid than that of the similarly sized peptides PINPRLDG and DGEQLADLIV (half-lifes of $15 \mathrm{~min}$; Fig. 8). The clearance of GVQLDLDEAI appeared to be biphasic with an initial phase of rapid clearance (half-life of 15-18 min) followed by a second phase in which clearance was slower. The rates of clearance did not vary when the dose of peptide infused was varied from 12.5 to $50 \mu \mathrm{g} / \mathrm{ml}$ (data not shown). Although the reason for this difference is not readily apparent, one might expect that the clearance of GVQLDLDEAI bound to C4b-binding protein would be reduced. Regardless, the clearance of GVQLDLDEAI is slow enough to allow the attainment of plasma levels comparable to those used in the in vitro studies.

Plasma samples obtained from rabbits after infusion with varying doses of GVQLDLDEAI exhibited an enhanced anticoagulant response to rabbit activated protein $C$ (Fig. 9). This effect was found to be dose-dependent and half-maximal stim- ulation occurred at a peptide concentration of $5 \mu \mathrm{M}$ (in good agreement with the effect seen in vitro). There was no effect on factor Xa-initiated coagulation if activated protein $\mathrm{C}$ was not added, suggesting that administration of GVQLDLDEAI did not have a direct effect on coagulation. Infusion of a rabbit with PINPRLDG did not result in any enhancement of anticoagulation (Fig. 9). In addition, the relative concentrations of free protein $\mathrm{S}$ were determined by gel filtration in plasma samples taken from rabbits after administration of GVQLDLDEAI and in samples taken from the same animals before the infusion. The percentage of protein $\mathrm{S}$ bound to C4b-binding protein decreased from 35.3 to $23.3 \% 6$ min after infusion with $10 \mathrm{mg}$ of GVQLDLDEAI (corresponding to a plasma concentration of $31 \mu \mathrm{M}$ ). After $20 \mathrm{~min}$ (plasma concentration of $17 \mu \mathrm{M}$ ), the percentage of protein $\mathrm{S}$ in the highmolecular weight complex rose to $29.9 \%$. These results suggest that GVQLDLDEAI interferes with the protein S-C4b-binding protein interaction in vivo and increases the anticoagulant cofactor activity of rabbit protein $\mathrm{S}$.

\section{Discussion}

The protein $\mathrm{C}$ pathway is felt to be an important element in the regulation of blood coagulation. Hereditary deficiencies of both protein $C(38,39)$ and protein $S(40,41)$ have been described in association with a predisposition to thrombotic events. The importance of the formation of a complex between protein $\mathrm{S}$ and $\mathrm{C} 4 \mathrm{~b}$-binding protein is underscored by the report of a variant of protein $S$ deficiency in which nearly all of the protein $\mathrm{S}$ was found to be bound to $\mathrm{C} 4 \mathrm{~b}$-binding protein, resulting in low levels of free protein $S$ and a thrombotic diathesis (35). The recent identification of a domain of protein $\mathrm{S}$ that appears to be involved with its interaction with $\mathrm{C} 4 \mathrm{~b}$ binding protein (25) suggested a means by which one may test the hypothesis that the protein $\mathrm{S} / \mathrm{C} 4 \mathrm{~b}$-binding protein interaction plays a role in the regulation of coagulation in vivo.

It was necessary to consider several factors in the design of an animal model. To assess the importance of the protein $\mathrm{S} / \mathrm{C} 4 \mathrm{~b}-\mathrm{binding}$ protein interaction in vivo, the following conditions must be met: $(a)$ Protein $\mathrm{S}$ in that animal must function as a cofactor for activated protein $C$. (b) Protein S must bind to C4b-binding protein. (c) GVQLDLDEAI must be able to displace protein $\mathrm{S}$ from $\mathrm{C} 4 \mathrm{~b}$-binding protein. The structure and function of protein $\mathrm{S}$ has been well studied only in human and bovine plasma. Unfortunately, neither species is suitable for these in vivo studies. The peptide GVQLDLDEAI, which had been shown to enhance the anticoagulant activity of activated protein $C$ in vitro in human plasma, had no effect in bovine plasma. The reason that the protein S/C4b-binding protein interaction is not important in the regulation of bovine protein $\mathrm{S}$ is that bovine plasma contains very low concentrations of $\mathrm{C} 4 \mathrm{~b}$-binding protein.

Rabbits were chosen for use in these in vivo studies because rabbit models have already been used to study the activation of coagulation in vivo in neoplasia $(42,43)$ or endotoxin shock $(44,45)$, and thrombin activation of protein $C(46,47)$. The well-documented species specificity of activated protein $C$ has been shown to depend on its interaction with protein $\mathrm{S}$. Because the use of activated protein $\mathrm{C}$ from heterologous species, such as the human or cow, would not be appropriate for the study of the cofactor role of protein $\mathrm{S}$ in rabbits, protein $\mathrm{C}$ and 
A

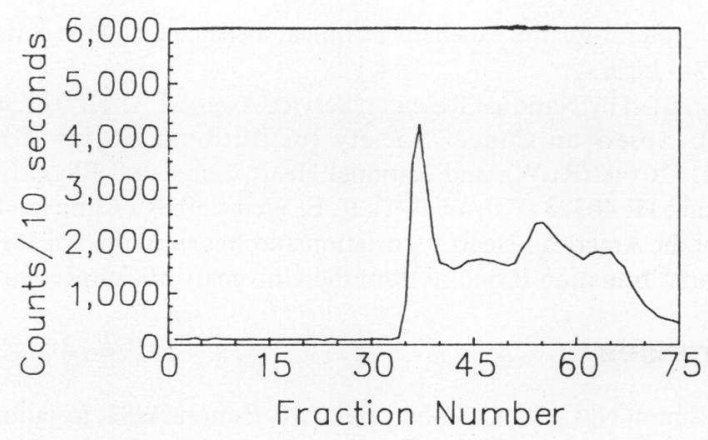

B

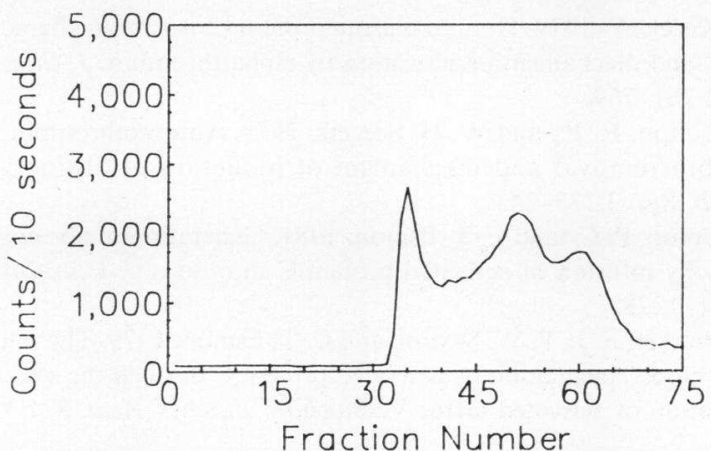

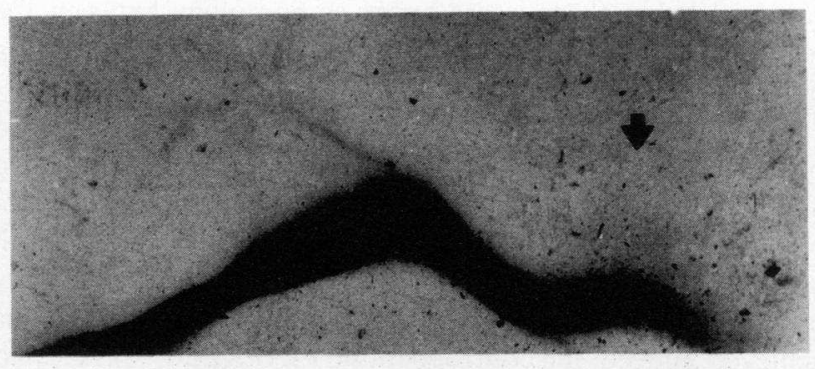

D

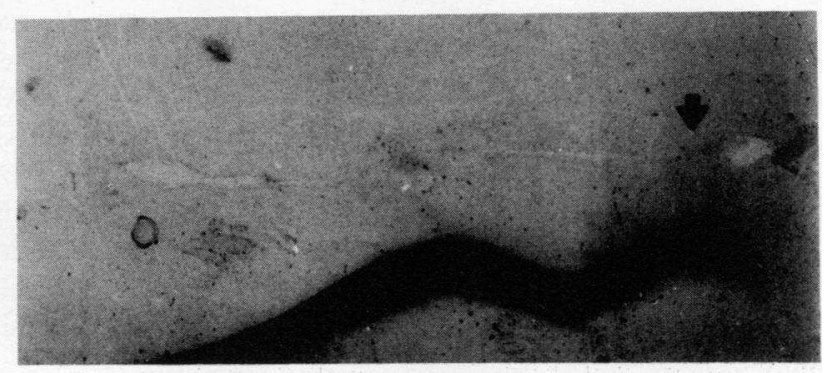

Figure 7. Effect of GVQLDLDEAI on the protein S/C4b-binding protein interaction in vitro in rabbit plasma. A mixture of ${ }^{125} \mathrm{I}$ rabbit protein $\mathrm{S}$ and rabbit plasma were gel filtered as described in Fig. 2. The percentage of ${ }^{125} \mathrm{I}$ protein $\mathrm{S}$ bound to $\mathrm{C} 4 \mathrm{~b}$-binding protein was $47 \%$ in the absence of GVQLDLDEAI $(A)$ and $34 \%$ in the presence of $150 \mu \mathrm{M}$ GVQLDLDEAI $(B)$. Two-dimensional immunoelectrophoresis of protein $S$ in rabbit plasma $(C)$ revealed peaks corresponding to protein $\mathrm{S}$ bound to $\mathrm{C} 4 \mathrm{~b}$-binding protein $($ left) and free protein $\mathrm{S}$ (arrows, right). The relative concentration of free protein $S$ was increased in the presence of $150 \mu \mathrm{M} \mathrm{GVQLDLDEAI}(D)$.

protein $\mathrm{S}$ were purified to homogeneity from rabbit plasma. As demonstrated in Results, rabbit protein $S$ is needed for the full expression of the anticoagulant activity of rabbit activated

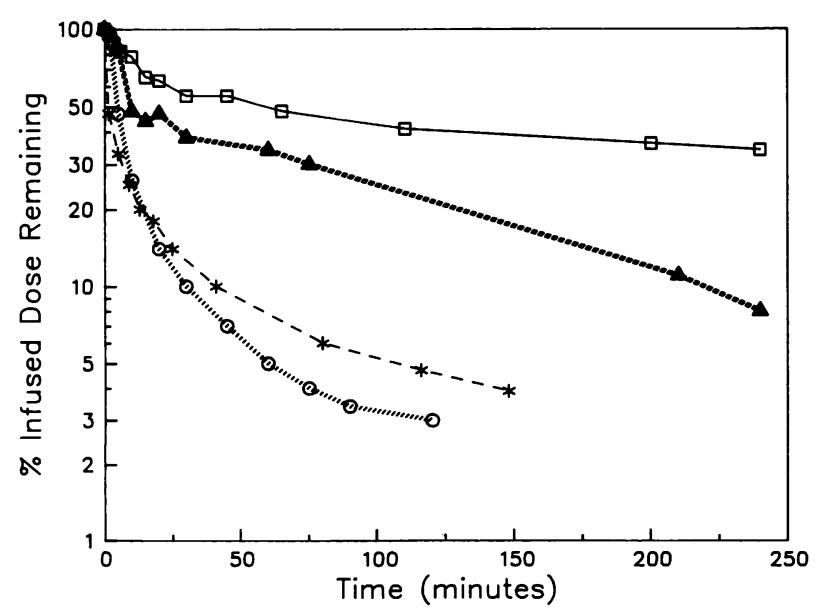

Figure 8. Clearance of peptides from rabbit circulation. Rabbits were injected with ${ }^{125} \mathrm{I}$ bovine protein S (open squares), fluorescein labeled GVQLDLDEAI (solid triangles), fluorescein labeled DGEQLADLIV (asterisks) or fluorescein-labeled PINPRLDG (open circles) and the percentage of infused dose remaining in the circulation determined at serial time intervals. protein $\mathrm{C}$ and seems to be regulated by formation of a complex with rabbit C4b-binding protein. Because GVQLDLDEAI increases the concentration of free protein $S$ in rabbit plasma

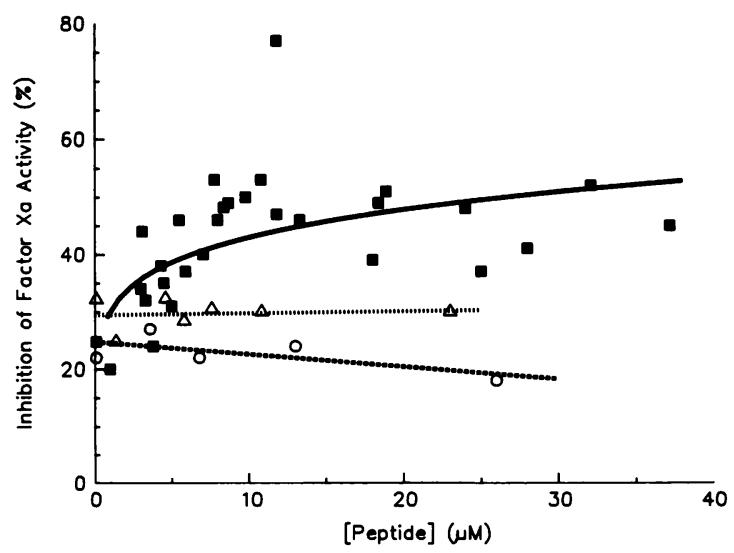

Figure 9. Enhancement of the anticoagulant activity of rabbit activated protein $C$ ex vivo by GVQLDLDEAI. Anticoagulant activity of $2 \mathrm{nM}$ rabbit activated protein $\mathrm{C}$ was measured in plasma samples obtained from six rabbits after infusion with GVQLDLDEAI (solid squares), DGEQLADLIV (open triangles), or PINPRLDG (open circles). The concentration of peptide in the plasma samples was estimated from the clearance curves shown in Fig. 8. The solid line was fitted by power regression analysis $\left(R^{2}=0.40\right)$. 
and enhanced its anticoagulant cofactor activity in vitro, we concluded that there is cross-species homology between the regions involved in the binding of protein $S$ to $C 4 b$-binding protein.

The results of the experiments conducted in the in vitro system indicated that the rabbit would be a good animal in which to study the interaction between protein $\mathrm{S}$ and $\mathrm{C} 4 \mathrm{~b}-$ binding protein in vivo. The major concern was that a small peptide such as GVQLDLDEAI would be cleared so rapidly from the circulation that effective plasma levels would not be achieved. Indeed, the control peptide PINPRLDG was cleared extremely rapidly (Fig. 8). The clearance of GVQLDLDEAI, on the other hand, was sufficiently slow to allow the attainment of effective plasma levels for several hours after a single intravenous injection. The reason for the less rapid clearance of GVQLDLDEAI is unclear. Because the interaction between GVQLDLDEAI and C4b-binding protein is approximately an order of magnitude weaker than that between protein $\mathrm{S}$ and C4b-binding protein ( $K_{\mathrm{d}}$ of $5 \mu \mathrm{M}$ vs. $100 \mathrm{nM}$ ) one would expect that only a small fraction of the injected GVQLDLDEAI would be bound to C4b-binding. Although GVQLDLDEAI bound to $\mathrm{C} 4 \mathrm{~b}$-binding protein is likely to be cleared less rapidly than unbound GVQLDLDEAI, it is unlikely that this accounts for the observed results. It is possible that GVQLDLDEAI binds to other circulating proteins or to cell surface receptors, but we have not yet investigated these possibilities.

The findings that infusion of GVQLDLDEAI results in higher levels of free protein $S$ and enhances the anticoagulant activity of activated protein $\mathrm{C}$ ex vivo suggest that formation of a protein $\mathrm{S} / \mathrm{C} 4 \mathrm{~b}$-binding protein complex is important in the regulation of protein $S$ function in vivo as well as in vitro. More work is needed to further characterize the interaction between protein $\mathrm{S}$ and $\mathrm{C} 4 \mathrm{~b}$-binding protein. As described earlier (25) GVQLDLDEAI has relatively low affinity for C4bbinding protein. The optimum size and/or structure of peptides corresponding to this region of protein $\mathrm{S}$ has not yet been determined. In addition, it is possible that there may be more than one domain of protein $\mathrm{S}$ involved in its binding to $\mathrm{C} 4 \mathrm{~b}$ binding protein.

Because the clearance of GVQLDLDEAI is relatively slow, it may have efficacy as an anticoagulant or antithrombotic agent, either alone or in combination with activated protein $C$. Instances in which activated protein $\mathrm{C}$ may be useful include the treatment of thrombotic events in patients who cannot receive heparin, such as those with heparin-associated thrombocytopenia, and at the start of anticoagulation in patients with protein $C$ deficiency (48). If infused concurrently with activated protein $C$ in such a situation, the use of GVQLDLDEAI may reduce the dose of activated protein $C$ needed to achieve anticoagulation. Alternatively, GVQLDLDEAI may be useful in situations, such as disseminated intravascular coagulation, in which endogenous activation of protein $\mathrm{C}$ may be elevated. Recently, activated protein $\mathrm{C}$ has been shown to provide protection against endotoxin shock in a primate model (49). Use of GVQLDLDEAI, either alone or with activated protein $C$, may be of benefit in the treatment of sepsis in such a setting. The development of peptides that bind more avidly to $\mathrm{C} 4 \mathrm{~b}$-binding protein would further enhance the potential utility of modulation of protein $S$ regulation as a means to regulate coagulation.

\section{Acknowledgments}

We are grateful for the excellent technical assistance of Jane Kristan and Holly Jager.

Supported by National Research Service Award T 32 HL07324-08 (REW); American Cancer Society Institutional Review Grant ACSIN152C-48 (REW); and National Heart, Lung, and Blood Institute Grant HL40328 (F. J. Walker). R. E. Weinstein is a Clinician-Scientist of the American Heart Association and was supported in part by a Research Initiation Proposal from the University of Connecticut.

\section{References}

1. Esmon, N. L., W. G. Owen, and C. T. Esmon. 1982. Isolation of a membrane-bound cofactor for thrombin-catalyzed activation of protein C. J. Biol. Chem. 257:859-864.

2. Kisiel, W., L. H. Ericsson, and E. W. Davie. 1977. Anticoagulant properties of bovine protein $\mathrm{C}$ following activation by thrombin. Biochemistry. 16:5824-5831.

3. Kisiel, W. 1979. Human plasma protein C: isolation, characterization, and mechanism of activation by alpha-thrombin. J. Clin. Invest. 64:761-769.

4. Zolton, R. P., and W. H. Seegers. 1978. Autoprothrombin IIa: thrombin removal and mechanism of induction of fibrinolysis. Thromb. Res. 3:233-243.

5. Comp, P. C., and C. T. Esmon. 1981. Generation of fibrinolytic activity by infusion of activated protein $\mathrm{C}$ into dogs. J. Clin. Invest. 68:1221-1228.

6. Walker, F. J., P. W. Sexton, and C. T. Esmon. 1979. The inhibition of blood coagulation by activated protein $\mathrm{C}$ through the selective inactivation of activated factor V. Biochim. Biophys. Acta. 571:333342.

7. Marlar, R. A., A. J. Kleiss, and J. H. Griffin. 1982. Mechanism of action of human activated protein $\mathrm{C}$, a thrombin-dependent anticoagulant enzyme. Blood. 59:1067-1072.

8. Vehar, G. A., and E. W. Davie. 1980. Preparation and properties of bovine factor VIII (antihemophilic factor). Biochemistry. 19:401410.

9. Walker, F. J., S. I. Chavin, and P. J. Fay. 1987. Inactivation of factor VIII by activated protein C and protein S. Arch. Biochem. Biophys. 252:322-328.

10. Walker, F. J. 1980 . The regulation of activated protein $\mathrm{C}$ by a new protein: a possible function for bovine protein S. J. Biol. Chem. 255:5521-5524.

11. Di Scipio, R. G., and E. W. Davie. 1979. Characterization of protein $\mathrm{S}$, a gamma-carboxyglutamic acid containing protein from bovine and human plasma. Biochemistry. 18:899-904.

12. Dahlback, B. 1983. Purification of human vitamin K-dependent protein $\mathrm{S}$ and its limited proteolysis by thrombin. Biochem. $J$. 209:837-846.

13. Stenflo, J., and M. Jonsson. 1979. Protein S, a new vitamin K-dependent protein from bovine plasma. FEBS (Fed. Eur. Biochem. Soc.) Lett. 101:377-381.

14. Weinstein, R. E., F. R. Rickles, and F. J. Walker. 1990. Purifcation and preliminary characterization of rabbit vitamin K-dependent coagulation proteins. Thromb. Res. In press.

15. Walker, F. J. 1981. Regulation of activated protein C by protein S: the role of phospholipid in factor Va inactivation. J. Biol. Chem. 256:11128-11131.

16. Loedam, J. A., J. C. M. Meijers, J. J. Sixma, and B. N. Bouma. 1988. Inactivation of human factor VIII by activated protein C: cofactor activity of protein $\mathrm{S}$ and protective effect of von Willebrand factor. J. Clin. Invest. 82:1236-1243.

17. Marciniak, E. 1972. Inhibitor of human blood coagulation elicited by thrombin. J. Lab. Clin. Med. 79:924-934.

18. Walker, F. J. 1981. Regulation of bovine activated protein $C$ by protein $\mathrm{S}$ : the role of the cofactor protein in species specificity. Thromb. Res. 22:321-327. 
19. Dahlback, B., A. Lundwall, and J. Stenflo. 1986. Primary structure of bovine vitamin K-dependent protein S. Proc. Natl. Acad. Sci. USA. 83:4199-4203.

20. Lundwall, A., W. Dackowski, E. Cohen, M. Shaffer, A. Mahr, B. Dahlback, J. Stenflo, and R. Wydro. 1986. Isolation and sequence of the cDNA for human protein $\mathrm{S}$, a regulator of blood coagulation. Proc. Natl. Acad. Sci. USA. 83:6716-6720.

21. Baker, M. E., F. S. French, and D. R. Joseph. 1987. Vitamin $\mathrm{K}$-dependent protein $\mathrm{S}$ is similar to rat androgen binding protein. Biochem. J. 243:293-296.

22. Dahlback, B., and J. Stenflo. 1981. High molecular weight complex in human plasma between vitamin $\mathrm{K}$-dependent protein $\mathrm{S}$ and complement C4b-binding protein. Proc. Natl. Acad. Sci. USA. 78:2512-2516.

23. Dahlback, B. 1986. Inhibition of protein Ca cofactor function of human and bovine protein $\mathrm{S}$ by $\mathrm{C} 4 \mathrm{~b}$-binding protein. J. Biol. Chem. 261:12022-12027.

24. Walker, F. J. 1986. Identification of a new protein involved in the regulation of the anticoagulant activity of activated protein C. $J$. Biol. Chem. 261:10941-10944.

25. Walker, F. J. 1989. Characterization of a synthetic peptide that inhibits the interaction between protein $\mathrm{S}$ and $\mathrm{C} 4 \mathrm{~b}$-binding protein. $J$. Biol. Chem. 264:17645-17648.

26. Comp, P. C., R. R. Nixon, M. R. Cooper, and C. T. Esmon. 1984. Familial protein $S$ deficiency is associated with recurrent thrombosis. J. Clin. Invest. 74:2082-2088.

27. Klein, J. D., and F. J. Walker. 1986. Purification of a protein C activator from the venom of the Southern Copperhead snake (Agkistrodon contortrix contortrix). Biochemistry. 25:4175-4179.

28. Stenflo, J. 1976. A new vitamin K-dependent protein. J. Biol. Chem. 251:255-263.

29. Owen, W. G., C. T. Esmon, and C. M. Jackson. 1974. The conversion of prothrombin to thrombin. 1. Characterization of the reaction products found during the activation of bovine prothrombin. J. Biol. Chem. 249:594-605.

30. Dahlback, B. 1983. Purification of human C4b-binding protein and formation of its complex with vitamin K-dependent protein $\mathrm{S}$. Biochem. J. 209:847-856.

31. McConahey, P. J., and F. J. Dixon. 1980. Radioiodination of proteins by the use of the chloramine-T method. Methods Enzymol. 70:210-225.

32. Morrison, S. A. 1983. Kinetics of activation of human prothrombin. Use of a fluorescein-labeled derivative to obtain kinetic constants as a function of factor $\mathrm{V}$ concentration and activation state. Biochemistry. 22:4053-4061.

33. Vaitukaitis, J. 1981. Production of antisera with small doses of immunogen: multiple intradermal injections. Methods Enzymol. 73:46-59.

34. Walker, F. J. 1984. Protein S and the regulation of activated protein C. Semin. Thromb. Hemostasis. 10:131-138.
35. Comp, P. C., D. Doray, I. D. Patton, and C. T. Esmon. 1986. An abnormal plasma distribution of protein $\mathrm{S}$ occurs in functional protein S deficiency. Blood. 67:504-508.

36. Laemmli, U. 1970. Cleavage of structural proteins during the assembly of the head of bacteriophage T4. Nature (Lond.). 227:680685.

37. Morrissey, J. 1981. Silver stain for proteins in polyacrylamide gels: a modified procedure with enhanced uniform sensitivity. Anal. Biochem. 117:307-310.

38. Griffin, J. H., B. Evatt, T. S. Zimmerman, A. J. Kleiss, and C. Wideman. 1981. Deficiency of protein $\mathrm{C}$ in congenital thrombotic disease. J. Clin. Invest. 61:1370-1373.

39. Broekmans, A. W., J. J. Verltkamp, and R. M. Bertina. 1983. Congenital protein $\mathrm{C}$ deficiency and venous thromboembolism: a study of three Dutch families. N. Engl. J. Med. 309:340-344.

40. Schwarz, H. P., M. Fischer, P. Hopmeier, M. A. Batard, and J. H. Griffin. 1984. Plasma protein S deficiency in familial thrombotic disease. Blood. 64:1297-1300.

41. Comp, P. C., and C. T. Esmon. 1984. Recurrent venous thromboembolism in patients with a partial deficiency of protein S. $N$. Engl. J. Med. 311:1525-1528.

42. Falanga, A., and S. Gordon. 1985. Purification and characterization of cancer procoagulant: a cysteine protease from malignant tissue. Biochemistry. 24:5558-5567.

43. Lorenzet, R., G. P. Peri, D. Locati, P. Allavena, M. Colucci, N. Semeraro, A. Mantovani, and M. B. Donati. 1983. Generation of procoagulant activity by mononuclear phagocytes: a possible mechanism contributing to blood clotting activation within malignant tissues. Blood. 62:271-273.

44. Mathiason, J. C., E. Wolfson, and R. J. Ulevitch. 1988. Participation of tumor necrosis factor in the mediation of gram negative bacterial lipopolysaccharide-induced injury in rabbits. J. Clin. Invest. 81:1925-1937.

45. Ditter, H., F. R. Matthias, R. Voss, and E. Lohmann. 1988. Beneficial effects of prostacyclin in a rabbit endotoxin shock model. Thromb. Res. 51:403-415.

46. Lollar, P., and W. G. Owen. 1980. Clearance of thrombin from circulation in rabbits by high-affinity binding sites on endothelium. Possible role in the inactivation of thrombin by antithrombin III. $J$. Clin. Invest. 66:1222-1230.

47. Colucci, M., R. Triggiani, L. G. Cavallo, and N. Semeraro. 1989. Thrombin infusion in endotoxin-treated rabbits reduces the plasma levels of plasminogen activator inhibitor: evidence for a protein C-mediated mechanism. Blood. 74:1976-1982.

48. Clouse, L. H., and P. C. Comp. 1986. The regulation of hemostasis: the protein C system. N. Engl. J. Med. 314:1298-1304.

49. Taylor, F. B., A. Chang, C. T. Esmon, A. D'Angelo, S. ViganoD'Angelo, and K. E. Blick. 1987. Protein C prevents the coagulopathic and lethal effects of Escherichia coli infusion in the baboon. J. Clin. Invest. 79:918-925. 